\title{
Cervical Squamotransitional Carcinoma
}

National Cancer Institute

\section{Source}

National Cancer Institute. Cervical Squamotransitional Carcinoma. NCI Thesaurus. Code C40194.

A human papillomavirus-related cervical squamous cell carcinoma characterized by the presence of papillary structures with fibrovascular cores. It is covered with multiple layers of atypical cells that resemble cervical intraepithelial neoplasia 3. 